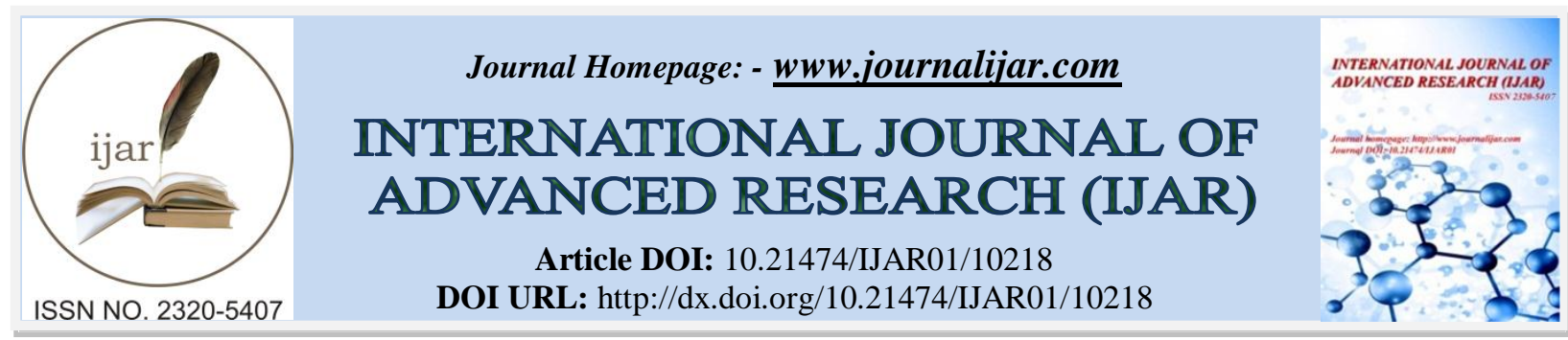

RESEARCH ARTICLE

\title{
PSYCHOLOGICAL HEALING IN ONCOLOGY - IN PURVIEW OF EPIGENETICS
}

\author{
Sabharwal Pooja ${ }^{1}$ and Sharma Akanksha ${ }^{2}$ \\ 1. Assistant Professor, PG Department of Rachana sharir, CBPACS New Delhi. \\ 2. PG Scholar, PG Department of Rachana sharir, CBPACS, New Delhi.
}

\section{Manuscript Info}

Manuscript History

Received: 10 October 2019

Final Accepted: 12 November 2019

Published: December 2019

Key words:-

Cancer, Tridoshas, Energetic Process

\begin{abstract}
Oncology is the study that specializes in diagnosis, research and treatment of cancer. A physician who works in the field and provides medical care for cancer survivors is an oncologist. Health can be managed by psychological healing procedures which can elevate mental status of patient and thereby Tridoshas becomes normal as Mansika and Sharirika bhavas affect each other. Cancer is the uncontrolled growth of abnormal cells when the body's normal control mechanism stops working these cells may form a mass of tissue, called a tumor. Environmental factors and bad lifestyle: such as smoking, alcohol consumption, stress, anxiety, depression, sun exposure etc. several elements can contribute to the development of the disease. These factors affect the ways that DNA communicates with cells. Life is a complex holistic entity and hence reductionistic approach of western modern health and life science. Hence the present article has been added to describe briefly the continuum of ecology- biologygenetic and energetic process of life and their application in Oncology.
\end{abstract}

Copy Right, IJAR, 2019,. All rights reserved.

\section{Introduction:-}

Cancer is the second most common cause of death in the United states. According to a recent study by American Cancer Society researchers, there are at least $42 \%$ of newly diagnosed cancers in the US. In 2019, 1,762,450 new cancer cases and About 606,880 Americans are expected to die of cancer, which translates to about 1,660 deaths per day. Over the past decade of data, the cancer incidence rate (2006-2015) was stable in women and declined by approximately $2 \%$ per year in men, whereas the cancer death rate (2007-2016) declined annually by $1.4 \%$ and $1.8 \%$, respectively ${ }^{1}$.Cancer is a distressing disease causing psychological problems among patients and their families. In the past few decades, there have been growing implementation and dissemination of screening methods for the psychological consequences of cancer, including distress, depression, anxiety, post-traumatic stress, and demoralisation. The psychological and social issues are often overlooked by the physicians while attending a patient with cancer. Several studies have shown the stress associated with cancer treatment might have a role in progression of cancer and cancer-related death ${ }^{2}$.

\section{Psychological relation with cancer epigenetics:}

More advanced research indicates that thought and mental stressful events are able to modify gene expression in various ways. Although the exact processes by which mind, thought, and consciousness arise within the brain have yet to be defined, according various research studies, it has been shown that the autonomic nervous system (ANS), which is generally regarded as a system that cannot be voluntarily influenced, can in fact be brought under some 
conscious level of control. Dutch individual suggested from a case study that he could voluntarily activate his ANS through a self-developed method involving meditation, exposure to cold temperatures, and breathing technique ${ }^{3}$. one another research experiment "mind over gene" revealed how mental exercise and meditation influence telomerase activity in subjects experiencing neuroticism, and these activities prevent telomere degradation ${ }^{4}$.

\section{Epigenesis in oncology:}

Epigenetics, play a basic significant role in human well being development and progression of degenerative diseases like cancer. Epigenetic modifications, can affect gene expression but they do not affect the sequence of DNA. Some genes influence the cells production of proteins, and proteins carry many of the instructions for cellular growth and division that would usually repair damaged cells, if changes in these genes expressions that can lead to cancer. If a parent has these genes, they may pass to their offspring on the altered instructions can cause cancer and some genetic changes occur after birth can increase the risk ${ }^{5}$. Epigenetics is a new field of research that focuses on the chemical modifications made to DNA that change phenotype without altering the underlying genetic sequence. The most common two epigenetic mechanisms are DNA methylation and histone modifications that impact gene expression.

\section{AyurvedicTreatment modalities:}

In Ayurveda Treatment methods is two types- Dravyabhuta chikitsa (drug therapy) and Adravyabhuta chikitsa (nondrug or non-pharmacological therapy) for both Sharirika and Mansika rogas (psychological diseases). Adravyabhuta chikitsa along with Dravyabhuta chikitsa is very significant treatment procedure to get desired and optimum results in different pathological conditions and physiology of healthy well being. Synonyms of Bheshaja or Aushadh is Pathya, Prayashchitta, Prashman and Hita also indicates the importance of Adravyabhuta chikitsa ${ }^{6}$. Various measures of Adravyabhuta chikitsa like Meditation, Yoga, Mantra, Pranic healing which have been described in scattered manner in Ayurveda are collected, compiled and discussed in this research paper. According to Acharya Charaka Daivavyapashraya, Yuktivyapashraya and Sattvavajaya are three types of Chikitsa ${ }^{7}$. Out of these three measures, Sattvavajaya and Daivavyapashraya chikitsa is the form of Adravyabhuta chikitsa which is related to nonpharmacological treatment for both maintenance of health and curing of diseases.

Treatment through psychological healing therapies- Epigenetics refers to cellular mechanisms that have emerged as a potential mechanism mediating the long-term effects of early adversity which control gene expression states, changes to the underlying DNA sequence. The epigenome can be highly dynamic and potentially influenced by lifestyle and environmental factors. A particular interest for the psychotherapy field lies in the potential for psychological healing interventions to influence epigenetic processes. Ayurvedic psychological healing therapies not directly observed but they act due to Prabhava property by enhancing the Satva guna and the person may become normal in psychological functions. In the case of mania, healing activities might be able to suppress the hyperactivity or stimulate the hypo-activity of Doshas through the control of Vata. Prana healing therapy, is one of its important treatment procedure that brings about the tranquility in mind by increasing Satva guna and elevate mental status along with physical Doshas i.e. Vata, Pitta and Kapha. Previous various researches shows that people can use yogic breathing techniques and exercises to reduce the impact of physical and mental stress at the level of gene. The effect involves no change to the person's inherited DNA sequence itself, but its expression significantly changes-influenced by one's emotional state. These epigenetic effects involve chemical modifications of gene regulator regions and have been shown to be heritable, This means the new genetic marks and expressed traits can be passed on to the next generation via epigenetic modifications ${ }^{8}$.

\section{Review of Literature:-}

Cancer Initiation is thought to often involve a primary mutation in the DNA leading to a cell with increased potential for growth but still dependent on additional genotypic and epigenetic changes to achieve complete transformation to malignancy. Often, if these co-required epigenetic changes do not occur, the mutation will not manifest into cancer. Epigenetic processes may also be involved in cancer initiation. It is possible that epigenetic change may lead directly to cancer initiation ${ }^{9}$. The mind(Mana) approach of Ayurveda includes the Meditation program to reduce psychosocial stress and optimize neurophysiological effects on mental, physical and social health. Orem-Johnson investigated the health insurance records of more than 2000 people practicing the meditation program over five years. The results showed significantly less health care utilization by the meditation practitioners for all 11 major disease categories including heart disease and cancer ${ }^{10}$. Non-pharmacological procedures can act as an adjuvant or a co-therapy along with chemotherapy or radiotherapy and help to minimise the side effects of these therapies. Pranic healing procedures help to slow the progress of cancer in cases where chemotherapy, radiotherapy or surgery is 
contra-indicated, and patients have no other choice. Psychological healing helps to improve the quality of life of cancer individuals and their families. Ayurveda is divided into four categories as Prakritisthapani chikitsa (health maintenance), Rasayana chikitsa, (restoration of normal function), Roganashani chikitsa (disease cure) and Naishthiki chikitsa (spiritual approach) ${ }^{11}$. According to Ayurveda Naishthiki chikitsa include yoga, meditation techniques like as Pranic healing. Mind-body healing techniques such as Pranic healing that can help in the management and treatment of diseases along with genetic basis, with their power in alleviating pain related symptoms associated with chronic conditions $^{12}$. Ayurveda analyzes the person with relation to their mind as well as their physical body to determine the correct treatment of the imbalance. This imbalance is not a factor of changing DNA rather an epigenetic factor that can be modified in relation to the patient's actions and environment ${ }^{13}$. Pranic healing procedures work at the psychological and physiological levels simultaneously, before modifying the epigenome ultimately associated with changes at the transcriptional level. It has also been suggested that meditation technique influences telomere length in a positive way by reducing cognitive stress and stress arousal, increasing positive states of mind, and stimulating hormonal factors that promote telomere maintenance, altogether decelerating cellular senescence ${ }^{14}$. Meditation is often used as a preventative activity against "lifestyle diseases" such as cancer, obesity, and diabetes. For example, a study involving a male population with low-risk prostate cancer that participated in an exclusive, intensive nutrition and lifestyle intervention (meditation, yoga guided imagery with a specially designed diet) showed significant improvements in weight, abdominal obesity, blood pressure, and lipid profile with beneficial changes in gene

expression and modulation of signaling pathways meditation can be used as a therapy for treating neurodegenerative diseases such as Alzheimer's by preventing cognitive decline ${ }^{15}$. Thus, meditation should be considered as a potential candidate for alteration of gene expression in a safe and beneficial fashion. Experts from the universities conclude that, when examined together, the 18 studies -featuring 846 participants over 11 years-reveal a pattern in the molecular changes which happen to the body as a result of mind-body interventions, and how those changes benefit our mental and physical health. The researchers focus on how gene expression is affected; in other words the way that genes activate to produce proteins which influence the biological make-up of the body, the brain and the immune system. When a person is exposed to a stressful event in their life, their sympathetic nervous system (SNS) is triggered, in turn increasing production of nuclear factor kappa B (NF-kB) which regulates our genes expression. $\mathrm{NF}-\mathrm{kB}$ activating genes to produce cytokines proteins and translates stress that cause inflammation at cellular level that is useful as a short-lived reaction, but if persistent leads to a higher risk of cancer. People who practice MBIs exhibit the opposite effect-namely a decrease in production of NF-kB and cytokines, leading to a reversal of the proinflammatory gene expression pattern and a reduction in the risk of inflammation-related diseases and conditions ${ }^{16}$. By Pranic healing frequently, physically recover better from stress and reduce harmful inflammation and this evidence suggests that It may also protect telomere parts of your chromosomes that are central to gene expression. Telomeres activities linked to psychological stress and physical health and the enzyme telomerase, which helps to rebuild and lengthen telomeres, are important to health. Telomere dysfunction or shortening has been linked to the development of tumors. In previous study published in Cancer, researchers found distressed breast cancer survivors who engaged in mindfulness meditation could maintain their telomere length, but those that didn't undergo meditation actually saw their telomeres decrease in length ${ }^{17}$. A small study done by Dr. Dean Ornish and scientists at University of California, San Francisco found that men with low-risk prostate cancer who underwent an hour long breathing and meditation exercise every day along with other activities like yoga or walking had decreased expression in genes associated with cancer ${ }^{18}$. Different Pranic healing techniques to purify an energy field center that is Chakra are there. These are the conscious process for raising us from our animal instincts to normal discrimination and elevating us to manifest the immune potentialities elements in us. These not only work to bring fitness and vigor to the physical body but also happiness, our will and emotions and to expand our power of analysis, insight and vision. Thus, these are becoming ore and more popular is becoming relevant even for cancer ${ }^{19}$.

\section{Discussion:-}

The basics fundamental theory of Ayurveda based on Prakriti, Vata (nervous system), Pitta (venous system) and Kapha (arterial system) and individual Prakriti roughly resembles our DNA, or our genes. These three basics are Tridoshas of our body which very important for normal body physiology. In cancer patients all Tridoshas get out of control and lose equilibirium that causes tissue damage, resulting critical condition. In cancer survivors Radiations, Chemicals, Poor life style, Mental Stress, Oxidative stress cause disturbance the energy field (Shadchakras) and low immunity. These factors Disturbs the Prakriti (Genotype) due to disturbance of (Phenotype)Vata, Pitta, Kapha Satwa, Raja, Tama that is DNA mutation which ultimately cause Cancer. Epigenetic marks are a subtle bio-energetic flaw that may be present in the systems of the body. In Ayurveda, Tridosha imbalances result in epigenetic marks 
which in turn cannot be repaired until a level of doshic integrity and coherence is achieved and stabilized. However, the epigenome has a reversible property since it is based on removable residues on genomic DNA. Thus, environmentally induced epigenomic alterations can be potentially restored. Epigenetic changes can also introduce for genetic instability and have a major role in the development of human cancer. So we are identifying exciting possibilities to alter the trajectory of chronic diseases, including cancer. Here we discuss a specific therapeutic strategy based on the concept that a subtle, life-force energy pervades all living things. Balancing this proposed lifeforce energy is the goal of energy therapies. These therapies can help people relax and may improve quality of life. Chakra balancing is a technique that aims to cleanse and balance the life-force energy in a person's body. This therapy can possibly be of great help in caring for cancer patients and reducing complications of the disease. However, further studies are needed to explore the impact of Shadchakras healing on additional clinically relevant measures.

\section{Conclusion:-}

The pranic healing technique through chakras balancing are unconventional non-pharmacological way of healing of the mind and body for healthy immune and disease free life in living. Working on the Chakras on daily besis helps to get rid of many disease. Ayurveda describe three modalities of treatment namely the Daivavyapasraya, Yuktivyapasraya and Satvavajaya into the nature of living systems. Based on this review, A statement can be said that the implication of Shadchakra pranic healing as a non-invasive non pharmacological intervention like Satvavajaya and Daivavyapashraya chikitsa for improving the psychological health status in patients with cancer. It seems that this method can be used as a safe method in the management of physical function, pain, anxiety, depression and nausea in cancer survivors and increase a sense of well-being and improve quality of life. Thus, it can be concluded that pranic healing is effective in reduction of stress, which is cause itself, \& a major side effect of cancer.

\section{References:-}

1. Siegel RL, Miller KD, Jemal A. Cancer statistics, 2019. CA: A Cancer Journal for Clinicians. 2019;69(1):7-34.

2. Karunanithi G, Sagar RP, Joy A, Vedasoundaram P. Assessment of psychological distress and its effect on quality of life and social functioning in cancer patients. Indian J Palliat Care 2018;24:72-7

3. Kox M., Stoffels M., Smeekens S. P., et al. The influence of concentration/meditation on autonomic nervous system activity and the innate immune response: a case study. PsychosomaticMedicine. 2012;74(5):489494.doi:10.1097/psy.0b013e3182583c6d. [PubMed] [CrossRef] [Google Scholar]

4. Kanherkar RR, Stair SE, Bhatia-Dey N, Mills PJ, Chopra D, Csoka AB. Epigenetic Mechanisms of Integrative Medicine. Evid Based Complement Alternat Med. 2017;2017:4365429. doi:10.1155/2017/4365429

5. Rachel Nall MSN. Cancer: Overview, causes, treatments, and types [Internet]. Medical News Today. MediLexicon International; 2018 [cited 2019Nov20]. Available https://www.medicalnewstoday.com/articles/323648.php

6. Agnivesha, Charak Samhita, Vidyotini Hindi Commentary, Shastri Kashinatha and Chaturvedi Gorakhanatha, Chikitsasthana, Abhayamlakiya Rasayanapada adhyaya (1[1]; 3), P. 2, Chaukhambha Bharti Academy, Varanasi, 2012.

7. Dwivedi L, Goswami PK. Charak Samhita of Maharshi Agnivesh. 3rd ed. Vol. 1. Varanasi: Chowkhamba Krishnadas Academy; 2014. p.273.

8. Gerson S. Ayurvedic Medicine and the Epigenetics of Lyme Disease by Dr. Scott Gerson (Part One) [Internet]. GIAM. GIAM; 2019 [cited 2019Nov20]. Available from: https://www.gersonayurveda.com/giamblog/2019/5/20/ayurvedic-medicine-and-the-epigenetics-of-lyme-disease-by-dr-scott-gerson-part-one

9. Jacobs T. L., Epel E. S., Lin J., et al. Intensive meditation training, immune cell telomerase activity, and psychological mediators. Psychoneuroendocrinology. 2011;36(5):664-681.

doi: 10.1016/j.psyneuen.2010.09.010. [PubMed] [CrossRef] [Google Scholar]

10. Pooja et.al. Intervention of Ayurveda as Bioenergetic Medicine In Healthy Aging- In Purview of Epigenetic : A Systematic Review. European Journal of Pharmaceutical and Medical Research. 2019Apr18,6(6);:339-47.

11. Thatte U, Dhahanukar S. Ayurveda, The natural alternative, Sci Today. 1991;2001:12-8.

12. Dusek J. A., Otu H. H., Wohlhueter A. L., et al. Genomic counter-stress changes induced by the relaxation response. PLoS ONE. 2008;3(7) doi: 10.1371/journal.pone.0002576.e2576 [PMC free article] [PubMed] [CrossRef] [Google Scholar]

13. Pooja Sabharwal, Rima Dada and Chetan Prakash. 2018. "Cancer and epigenetics interrelationship in prevention and cure", International Journal of Development Research, 8, (08), 22163-22168. 
14. Epel E., Daubenmier J., Moskowitz J. T., Folkman S., Blackburn E. Can meditation slow rate of cellular aging? Cognitive stress, mindfulness, and telomeres. Annals of the New York Academy of Sciences. 2009;1172:34-53. doi: 10.1111/j.1749-6632.2009.04414.x.[PMC free article] [PubMed] [CrossRef] [Google Scholar]

15. Innes K. E., Selfe T. K. Meditation as a therapeutic intervention for adults at risk for Alzheimer's diseasepotential benefits and underlying mechanisms. Frontiers in Psychiatry. 2014;5, article 40doi: 10.3389/fpsyt.2014.00040. [PMC free article] [PubMed] [CrossRef] [Google Scholar]

16. Meditation and yoga can 'reverse' DNA reactions which cause stress, new study suggests [Internet]. ScienceDaily. ScienceDaily; 2017 [cited 2019Nov20]. Available from: https://www.sciencedaily.com/releases/2017/06/170615213301.htm

17. Carlson, L. E., Beattie, T. L., Giese-Davis, J., Faris, P., Tamagawa, R., Fick, L. J., Degelman, E. S. and Speca, M. (2015). Mindfulness-based cancer recovery and supportive-expressive therapy maintain telomere length relative to controls in distressed breast cancer survivors. Cancer, 121: 476-484.

18. Ornish, D., Magbanua, M.J., Weidner, G., Weinberg, V., Kemp, C., Green, C., Mattie, M.D., Marlin, R., Simko, J., Shinohara, K., Haqq, C.M., Carroll, P.R. (2008). Changes in prostate gene expression in men undergoing an intensive nutrition and lifestyle intervention. PNAS, 834 105(24): 8369-8374.

19. Pooja S, Bibhuprasad N, Akanksha S. Pranic Healing: A Stress Buster For Cancer Patients. International Journal of Advanced Research. 2019;7(1):380-4. 